\title{
GROWING VEGETATION ON MINE RESIDUE DUMPS
}

\author{
Bill Cook \\ Manager \\ Chamber of Mines of South Africa
}

Vegetation Unit

The gold mining industry of the Witwatersrand Basin has, since its inception in 1886, milled and dumped about 5000 million tons of rock on the surface of the highveld. That is more than 38 times as much material as was moved to create the Suez Canal. This vast tonnage, if deposited in a conical shaped heap, would form a mountain higher than Table Mountain and with a base covering the equivalent of 30000 tennis courts.

Instead, of course, it has been spread across hundreds of kilometres in the form of golden sand dumps and flattish yellow residue heaps of initially-wet powdery material, known locally as slimes dams. Between Randfontein and Nigel - the limits of the Witwatersrand with a population of $2 \frac{1}{2}$ million - there are some 247 slimes dams and 95 sand dumps. These "heaps of potential dust" give Johannesburg in particular a distinctive appearance and are sometimes admired by photographers and artists who do not have to live close to them.

Their bleak, sandy or dusty surfaces wash away easily and sometimes cause stream pollution. Fine dust blows off them on windy days and settles on verandas and gardens and in people's eyes.

The task of the Chamber of Mines Vegetakion Unit is to treat these residue dumps of the gold mines in such a - way as to stop air and water pollution. The task was undertaken voluntarily many years ago, in the public interest. 
A first task was to find plants which could tolerate

some degree of acidity. Seeds eventually selected were

New Zealand Brown Top, Rescue Grass, Rhodes Grass, Cocksfoot, Weeping Love Grass, Yorkshire Fog, Kentucky Blue, Fescue Type 31, Canary Grass, Clovers (2 varieties), Creeping Saltbush, Lucerne, Blackwood Tree and Silver Wattle Tree, and plants selected were Star Grass, Pampas Grass, Australian Blue Bush, Hippo Grass and Sour Fig. Some are available from seed merchants but others have to be propagated.

Each dump and dam presents its particular problems, main$7 y$ in regard to its site, degree of fineness of milling, angle of slope, stability and above all the degree of pyrite content and hence acidity. But basically there are four types of surface -

1. Surface with very high acid content. It is sometimes necessary to form water traps by ridge ploughing and contouring where rainwater can lie for one or two seasons to naturally leach much of the acid into the interior of the dump which is alkaline.

2. Surfaces with medium acid content. Much of the acid may be leached deeper into the dump and below plant roots by gentle spraying with water by means of polythene pipes supported on stilts and fitted with jets about three metres apart. On slopes the surface must not be drenched as this may cause erosion, and "slip". Water for sprays usually comes from underground sources or mine dans. The sprays are used to leach the acidity down into the alkaline zone of the dump. This water is also used to establish vegetation while the acid level is being lowered. The medium acid content surfaces may be treated in the same way as .....

3. Flat surfaces with low acid content. These form the mass of area to be vegetated. After erosion gullies have been smoothed and perimeters banked up and contour walls at 45 centimetre falls constructed, the dryland vegetation method is used -

(a) Apply 3 tons an acre of agricultural lime, after cultivating, to form a holding surface, if conditions are windy.

(b) Rotovate about $75 \mathrm{~mm}$ deep with a tractor powered fotovator.

(c) - Mix the seed valifeties to be used after adding legime innoculants 
and boiling Acacia seeds in water for 2 minutes to aid germination. Sow seeds using agricultura] 1ime as a distribution and germination aid and simultaneously apply 300 1 bs of superphosphate an acre.

(d) Rol1 the area sown with a Cambridge (ribbed) roller to corrugate the surface. Complete all operations described so far on one day, as even light rain wil] seal the prepared seed bed which would then have to be re-rotovated.

(e) Four days after sowing, apply 2-3-2 fertilizer, 250 lbs an acre. When the vegetation reaches the third leaf stage apply the same amount of ferti]izer again.

(f) When the vegetation is established, say four or five weeks after germination, apply 50 lbs urea an acre, and the same amount 10 days later.

4. Surfaces which slope (the sides of slimes dams and most of sand dumps). Because most slopes are steep and eroded, seed beds are usually prepared and shaped by labourers using ordinary garden implements. Large breaks and gullies are levelled by heavy earth-moving equipment. Erosion-prone areas are dishshaped or strengthened by silt-catching barriers of reeds or bales of mulch.

In the case of sand dumps the sand whipped up by wind sandblasts young vegetation to death and windbreaks are necessary. Windbreak barriers are best provided by reed canes spaced at finger thickness, 27 inches above and three inches below the surface. The criss-crossing fences, forming enclosed protected paddocks, are spaced according to steepness of slope but, on average, one mile of windbreak is used on each acre of sand dump slope.

Slopes require water sprays to leach acid further into the surface, as described earlier. Detergents are sometimes used to assist moisture penetration into slimes. Leaching continues until the acidity is depressed to a depth of 1,3 metres and the vegetation is well established which could, under favourable conditions, be within four weeks. 
1. Smooth out erosion gullies and prepare a fine seed bed.

2. Spread a mulch of veld grass ( 80 bales an acre).

3. Spread three tons of agricultural lime an acre - more if necessary - to further lower dump surface acidity.

4. When acidity drops sow a seed mixture on top of the mulch, using agricultural lime (50 lbs an ac:re) as a distribution and germination aid.

5. Apply superphosphate (300 1bs an acre) and 2-3-2 fertilizer (250 lb an acre).

6 . Ten days after germination apply the same amount of 2-3-2 fertilizer followed 10 days later by urea (50 lbs an acre) with more urea later if necessary.

7. When vegetation is established samples of slimes are taken and analysed. If the acidity has not been lowered sufficiently apply an additional ton an acre of agricultural lime, and water it well in.

8. Remove leaching equipment and replace with "rainbird" sprays.

9. Continue watering (as opposed to leaching) until the vegetation will survive on natural precipitation.

The gold mining industry is spending $R 500000$ a year on vegetating dumps. Sand dumps cost from R200 to R350 an acre to vegetate and slimes dams from $R 200$ to $R 300$ in the case of tops and R425 to R625 in the case of slopes. These figures exclude the cost of repairing major breaks necessitating the use of earth moving equipment and of water consumed.

Animal, bird and insect life moves in as soon as vegetation begins to grow and on some of the oldest vegetated slimes dams where trees and grass have been established for nine years, buck, jackal and large birds and a varjety of rodents, including moles, are well established.

Vegetation has not only made the dumps and dams available for use as parks, game reserves, airports, schools and so on, but large tracts of neighbouring land which previous ly were menaced by dust have now become available for housing and industrial sites protected from the wind by green hills. 
The slimes dams and sand dumps are 25000 acres in area - though most are stj11 in use and being wet cause little pollution. The Vegetation Unit has to date vegetated about 5000 acres, including most of those around Johannesburg and the big towns, and a further 1000 acres a year are being treated.

The remarkable work of turning the gold hills of the Witwatersrand to green has won the admiration of people from many countries, including those who are trying to cover industrial refuse mining dumps elsewhere.

It is a fascinating thought that within five miles of the business heart of Johannesburg there are 3000 acres of flat dumpland which is now being turned into grassland. Compare that with the 600 acres of Hyde Park-Kensington Gardens available within five miles of the City of London and one gets some idea of Johannesburg's good fortune in having these once despised mine dumps now available as open areas. 